\title{
Evaluating Damage to a Typical Precast Warehouse Building**
}

\section{Introduction}

Evaluating the technical condition of building structures is essential for their safe use and rational renovation management. Inspection of the technical condition of building structures shall be done as part of mandatory periodic maintenance services (conducted annually and every 5 years) as well as construction expertise or technical opinions.

According to the Building Law [7] as well as the building and technical regulations $[5,6]$, the required effects of the inspection of building structures should include the following:

- description of a damage and the degree of wear of individual elements,

- evaluation of the technical condition of the elements subject to the inspection,

- recommendations for further use of the building,

- the scope of renovation works and refurbishment plan.

The purpose of this article is to present how important it is to evaluate the technical condition of building structures as well as to identify reasons for the observed damage to determine the manner of their repair. This was done on the example of a damaged warehouse building of a typical precast reinforced concrete load-bearing structure, commonly used in the 60 s and 70 s of the last century [1]. The immediate cause of the examination of the technical condition of this building was the user's concern caused by substantial damage to masonry exterior walls.

\section{Technical Description of the Structure}

The subject of the study is the warehouse built around 1965 on the territory of an industrial plant. It is a two-bay ground floor hall with no basement, of a typical

* AGH University of Science and Technology, Faculty of Mining Surveying and Environmental Engineering, Krakow, Poland

** This article has been prepared within the scope of the AGH UST statutory research no. 11.11 .150 .005 
precast reinforced concrete load-bearing structure. Probably, a typical building project in the CRS Unified Storage System was used here [2]. The floor plan of the warehouse is a rectangle with the dimensions of $48.70 \mathrm{~m}$ by $12.80 \mathrm{~m}$ and the height measured from the ground level to the roof ridge is $6.10 \mathrm{~m}$.

The load-bearing structure of the warehouse building consists of two-bay beam-pillar systems with a span of $6.0 \mathrm{~m}$, longitudinally spaced at $6.0 \mathrm{~m}$. Each of them is made of prefabricated T-bolts, based articulated on precast I-section beam columns, fixed in monolithic footings (c.f. Fig. 1). The outer curtain walls were designed as lime-and-sand brick masonry with a thickness of $25 \mathrm{~cm}$, with the use of cement and lime mortar. The support for curtain walls are monolithic reinforced concrete ground beams, supported on the plinths of the footings. Above the window openings, in the longitudinal walls, there is a continuous monolithic reinforced concrete beam based on the brackets of the supporting columns, which also functions as the lintels. Roofing of the warehouse building consists of a bipartite flat roof, whose joists are precast concrete slabs with a span of $2.0 \mathrm{~m}$ based on reinforced concrete purlins with a span of $6.0 \mathrm{~m}$. A non-insulated steel-structured roof covered with galvanized trapezoidal sheet is based on the joists.

There were no major renovations or maintenance works carried out in the building.

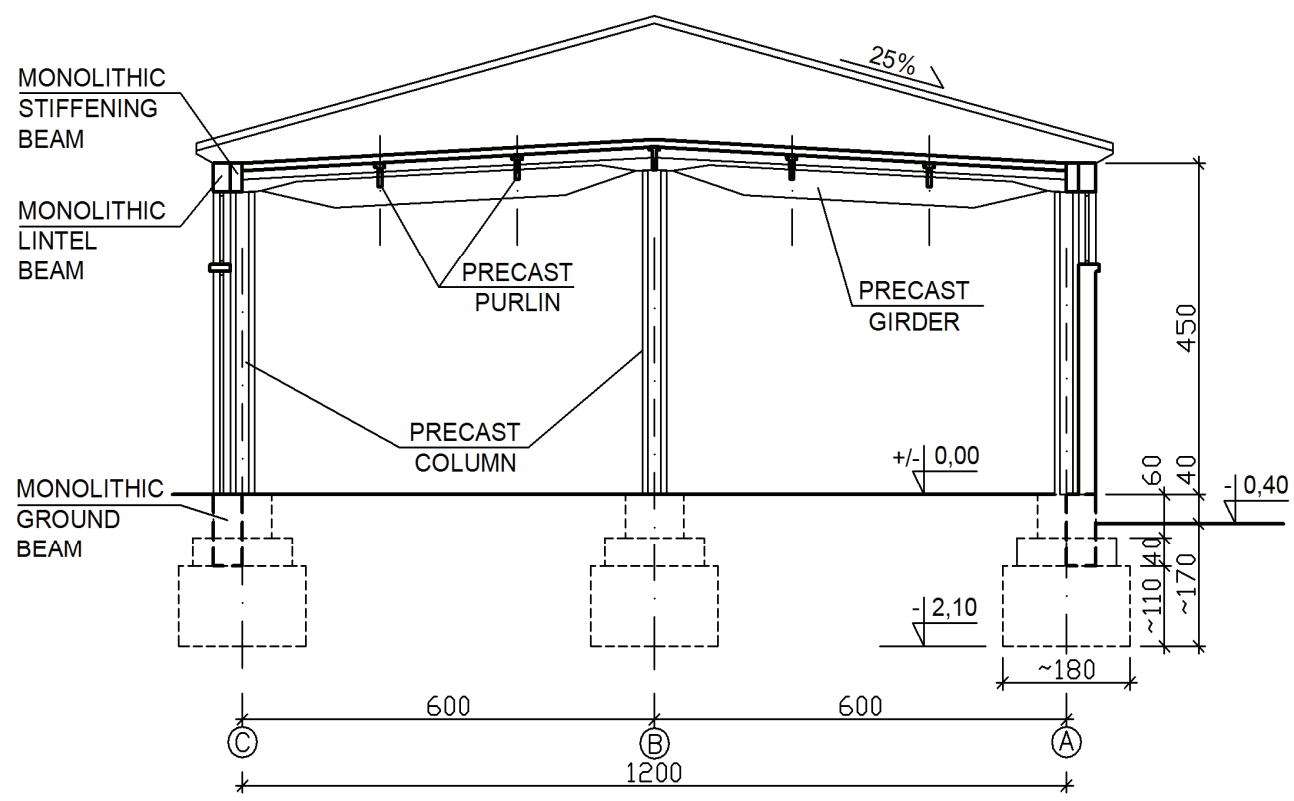

Fig. 1. Schematic cross-section of the warehouse 


\section{Damage, Irregularities and Causes of Their Occurrence}

Based on the conducted inspection, a brief description of the identified damage and irregularities was presented, which was documented in drawings and photographs (Figs 2-10), and their causes were determined as well. On the drawings, the scratches and cracks were marked in red and their width was given in millimeters.

\section{Damage to the load-bearing structure of the warehouse building:}

a) Cracks and losses of concrete along the edge of the column heads at the level of the girder support, and assembly mortar losses in the contact area of prefabricated elements (e.g. Fig. 2). This damage is mainly related to thermal deformations of a warehouse building with a length of $48.0 \mathrm{~m}$, which is not thermally insulated and does not have expansion joints. According to the standard PN-B-03264:2002 [4], the maximum allowable distance between expansion joints, in the case of the reinforced concrete frame construction subjected to varying outdoor temperatures, should be 30 meters.

b) Defective concrete cover along the edges of the individual elements of the reinforced concrete load-bearing structure, such as the columns, girders, purlins and stiffening beams (e.g. Fig. 3). The defective cover is primarily due to the poor quality of the precast elements as well as the damage during their transport, and wear of the building.

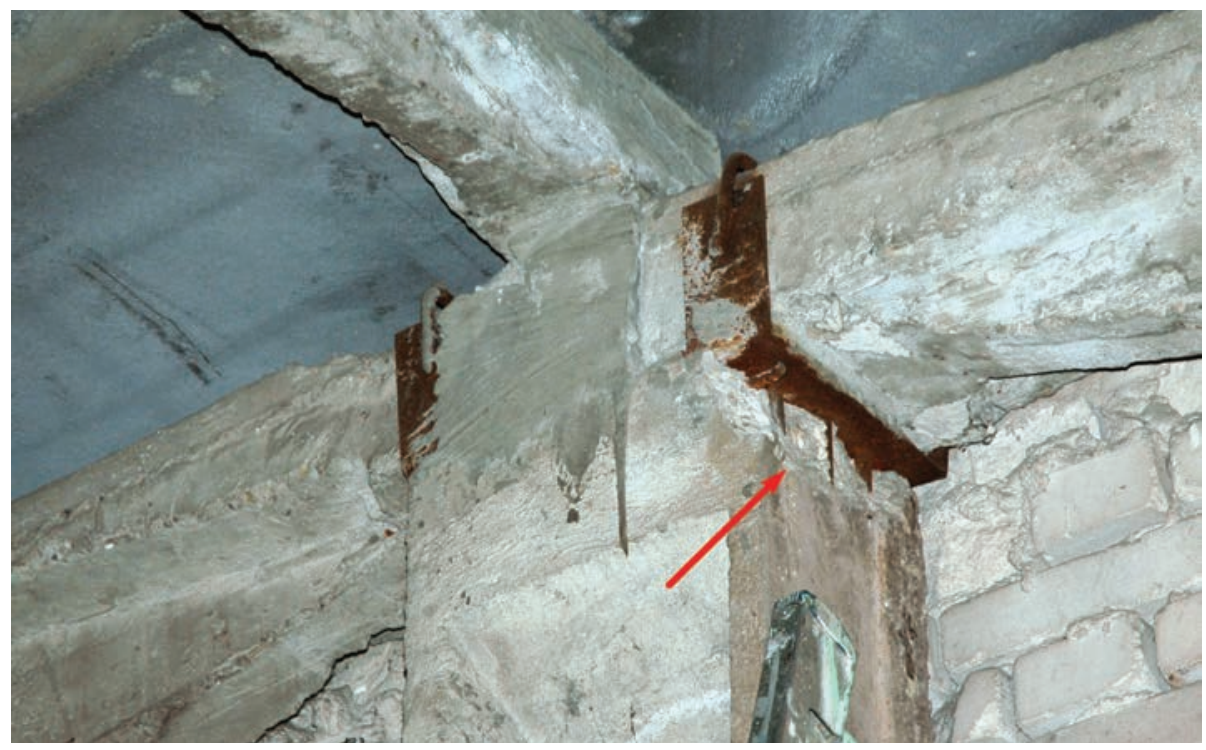

Fig. 2. The head of the central row column at the southern end wall.

Loss of concrete of the depth up to $4 \mathrm{~cm}$ along the edge of the column head, at the level of the girder suport 


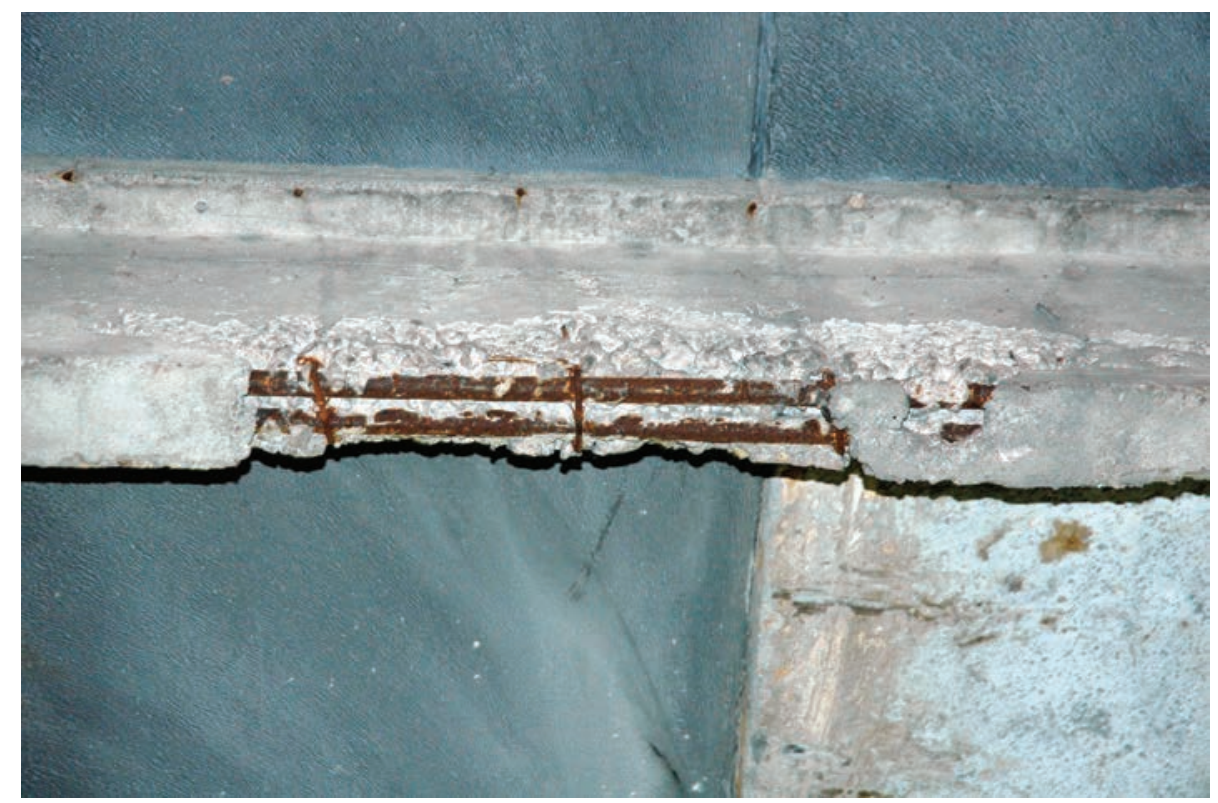

Fig. 3. The purlin in the middle part of the warehouse roof covering.

Loss of concrete cover along the bottom edge of the beam and corrosion of the exposed rebars

\section{Damage to the internal and external walls:}

c) Vertical and diagonal cracks in the exterior masonry curtain walls occurring near the columns of the load-bearing structure and in the areas weakened by the holes (e.g. Figs 4-8). These cracks were caused by:

- additional internal forces arising in the longitudinal walls in the area of the supporting columns that result from different static scheme of the wall and the ground beam; during the construction process, a continuous curtain wall was supported on single-span simply-supported ground beams, supported articulated on the neighboring footings;

- thermal deformations of the exterior masonry curtain wall with a length of $48.75 \mathrm{~m}$, which is not thermally insulated and does not have expansion joints; according to the standard PN-B-03002:2007 [3], the maximum distance between expansion joints in the case of the layers of the masonry wall subjected to varying outdoor temperatures, and made with other than ceramic small elements, should be $8 \mathrm{~m}$ and, in addition, expansion joints should be made also in the corners of the building; the expansion joint width must not be less than $20 \mathrm{~mm}$ and it should be filled with permanently elastic material. 


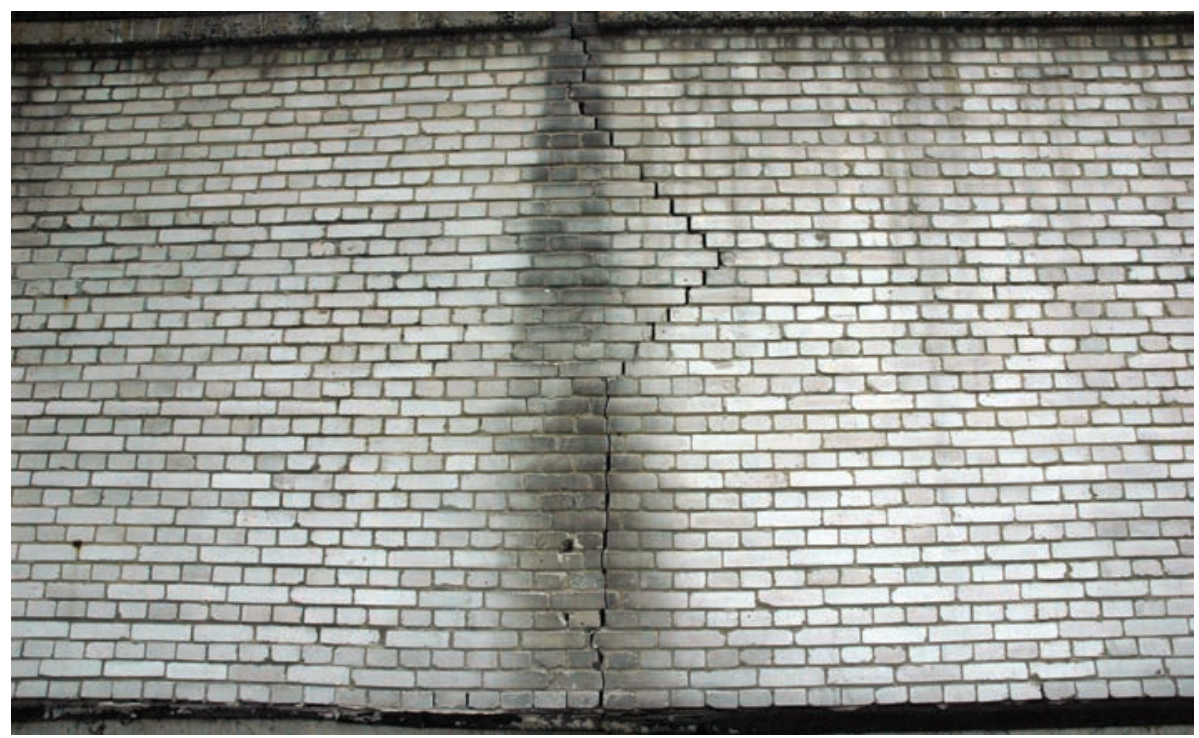

Fig. 4. Detail of the east elevation in the middle part - wall crack (up to $7 \mathrm{~mm}$ ) in the vicinity of the load-bearing structure column

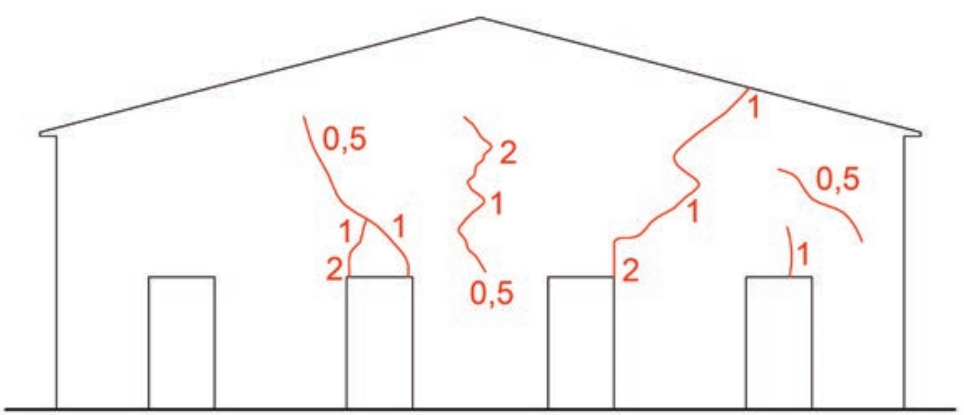

Fig. 5. Damage visible on the north elevation

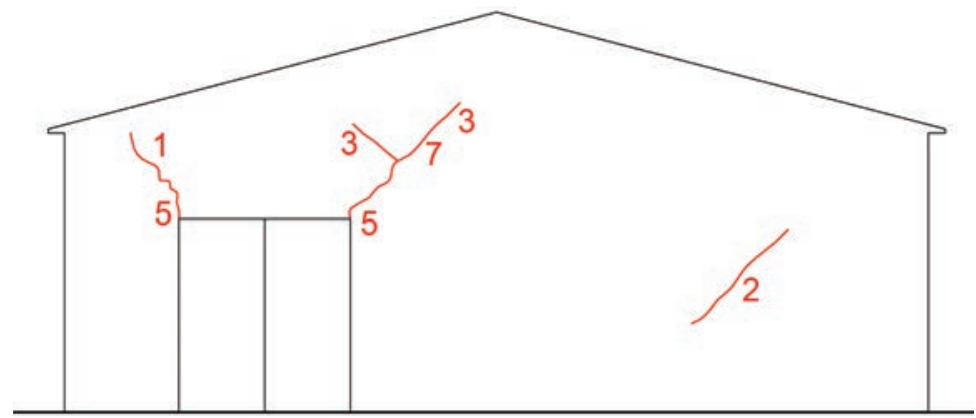

Fig. 6. Damage visible on the south elevation 

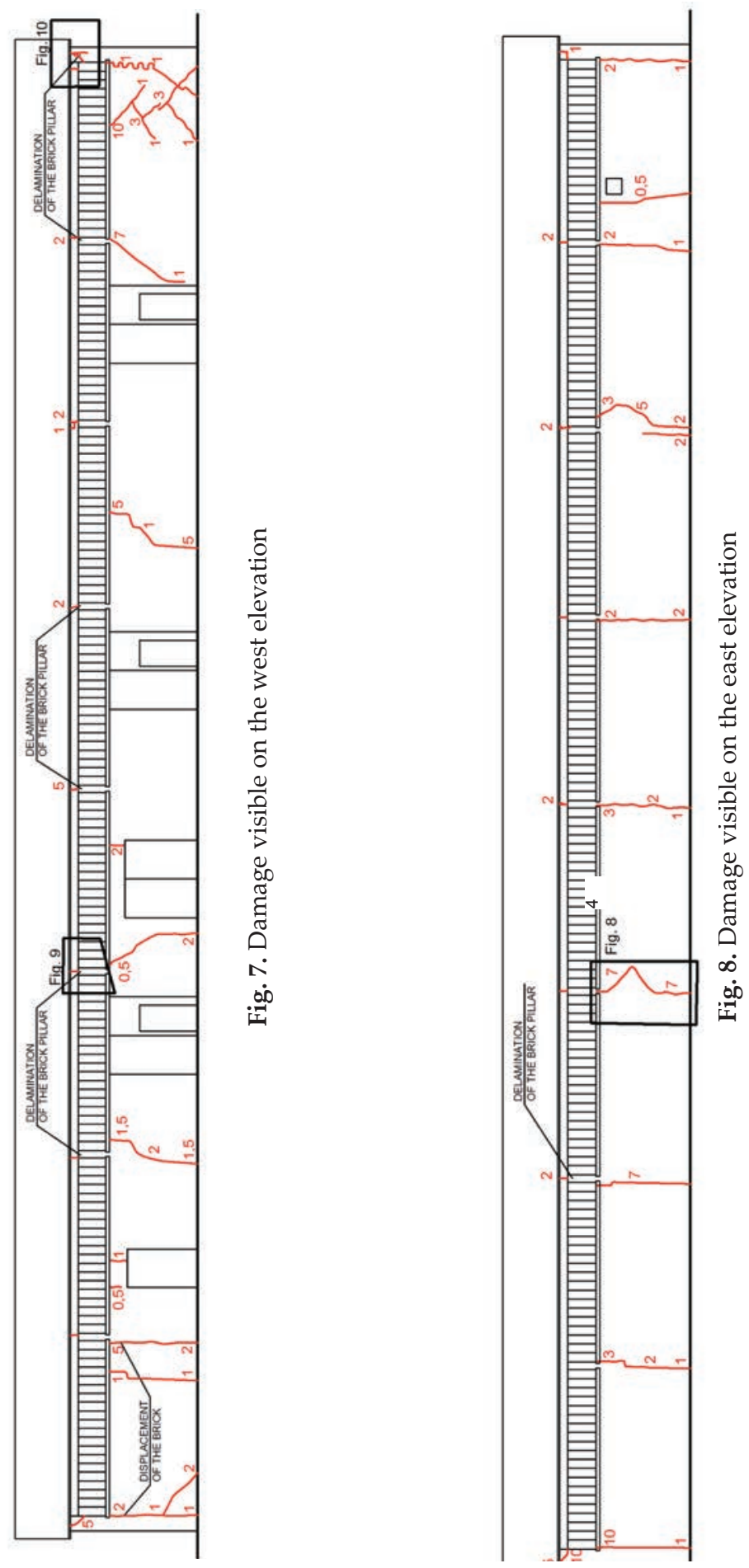
d) Numerous cracks, delamination and displacements of the masonry wall fragments of the western, longitudinal curtain wall near the north and south corners of the building, as well as cracks, delamination and demonolithizing of the fragments of brick pillars between the window openings (e.g. Figs 9, 10).

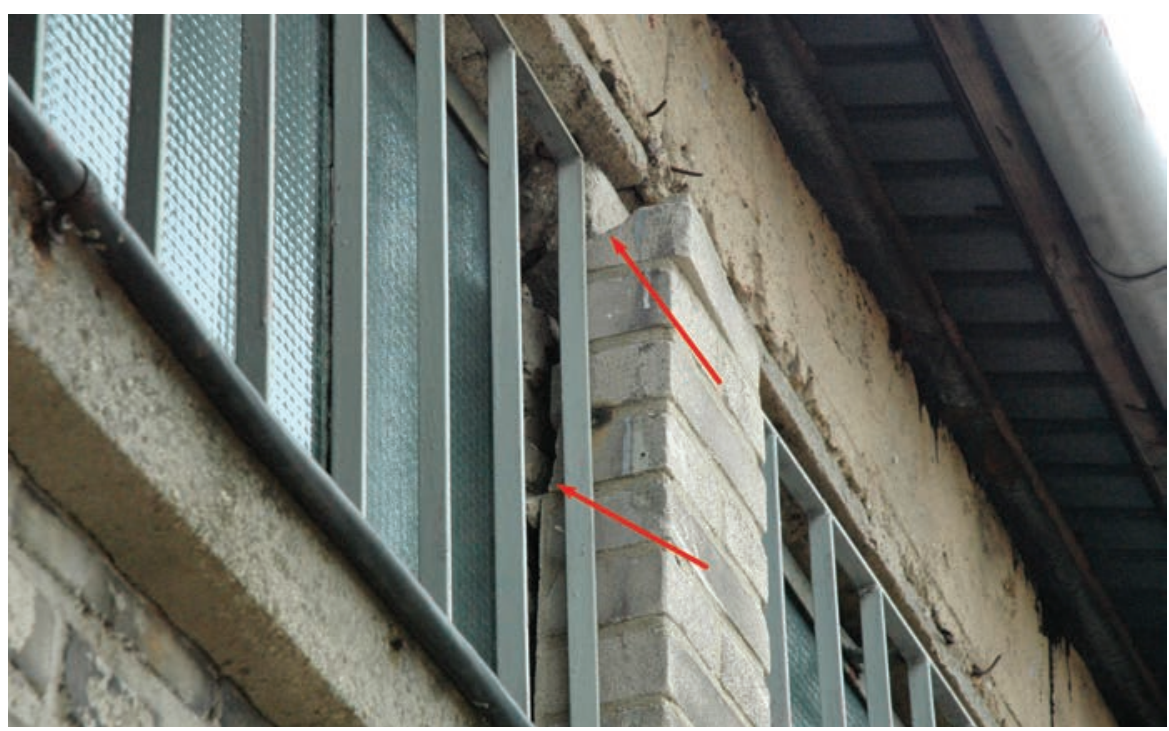

Fig. 9. Detail of the west elevation in the middle part - crack, displacement and delamination of a part of the brick pillar between the window openings

Besides the basic reasons described in section " $\mathrm{c}^{\prime \prime}$, an additional reason for the damage may be the uneven settlement of the foundations due to lack of drainage of rain water from the downspouts, and the lack of expansion joints at the contact point between brick pillars and continuous reinforced concrete lintel beam based on column brackets.

e) Scratches and cracks at the contact point between the internal masonry infill walls and the reinforced concrete load-bearing structural elements, as well as in the corners of the interior and exterior walls. That damage is due to the applied technology.

f) Cracks, intense corrosion, delamination and loss of concrete cover as well as the surface corrosion of the exposed rebars of the reinforced concrete monolithic lintel beams over the window openings along the external longitudinal walls (c.f. Fig. 10) and concrete window sills under the window openings. That damage is caused by poor quality of workmanship and moisture at gutters and roofing leaks, as well as the lack of flashings. 


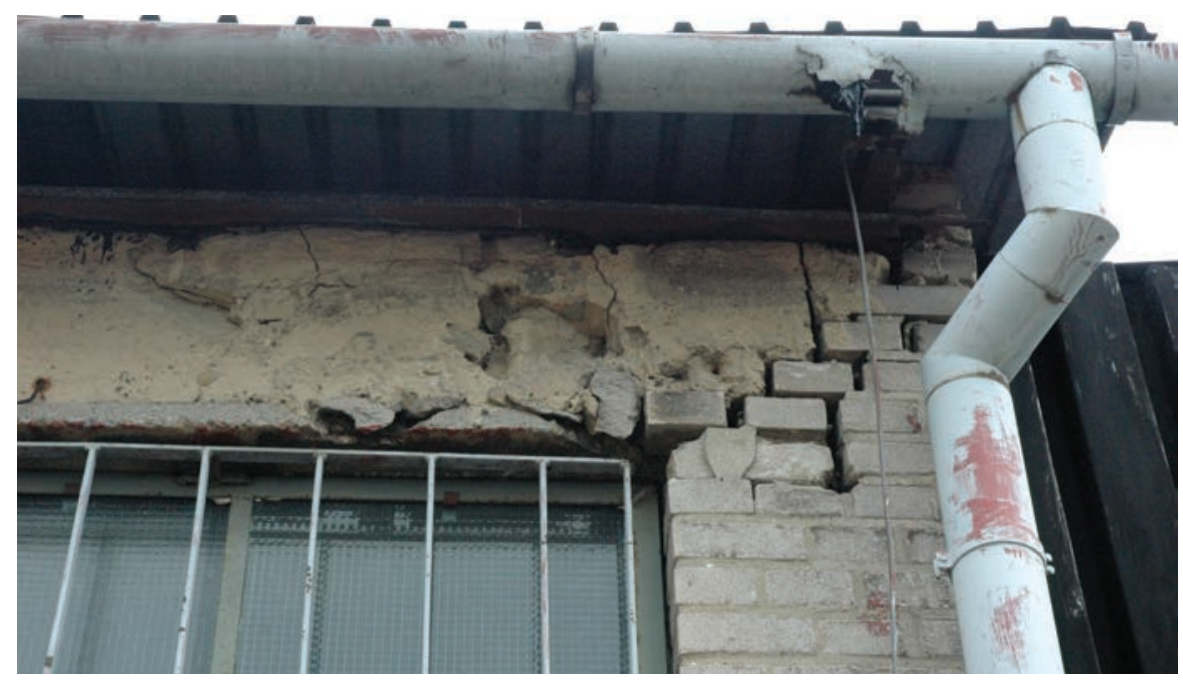

Fig. 10. Detail of the west elevation at the south corner - corrosion and delamination of the brick pillar as well as corrosion and cracking of the reinforced concrete lintel

\section{Evaluating the Technical Condition of the Warehouse}

Most of the above described damage to the warehouse load-bearing structure is characteristic of the prefabricated technology which was used here. Similar irregularities are common in other similar structures and result from both the imperfections of the technology and its incompetent use or careless workmanship and lack of maintenance services.

In the case of damage to the reinforced concrete load-bearing structural elements it was found that they do not pose a threat to the safety of the structure, so there is no need for construction safety measures to be taken. However, it is necessary to repair them. The most significant damage to the load-bearing structure are concrete cracks and losses along the edge of the column heads, which need to be repaired first.

In the case of damage to the external curtain walls it was found that they only were an inconvenience when using the warehouse. Only in the case of their continuous damage, can they become a safety hazard. In particular, it refers to the cracks and delamination and displacement of the curtain wall fragments as well as cracks, delamination, demonolithizing of the fragments of brick pillars between the window openings and cracks, delamination and losses of concrete cover in reinforced concrete lintel beams.

Based on a comparison of the current technical condition with the archival documents [2], there was no significant increase in the extent of damage to the structural elements and curtain walls identified. However, the progression of natural wear 
accelerated by the lack of ongoing maintenance and repairs was noticed, associated with the passage of time (45 years of use with an average life of approximately 60 years [8]).

In general, in the applied [8] six-grade scale (very good, good, fair, average, bad, very bad), the technical condition of the warehouse building was rated as average.

It was claimed that the structure could still be used for its intended purpose, and it was recommended to carry out repair works, the scope of which was given below.

\section{The Scope of the Recommended Repair Works}

In order to allow for the continued safe use of the warehouse building, it was recommended to carry out the following maintenance works.

Re-profiling of the damaged column heads in the middle row was deemed as the most urgent. Repair of other elements of the reinforced concrete load-bearing structure can be done in the second place. It was recommended to carry out the repairs using one of the technology-and-material systems with concrete repair mortar.

The repair of the damaged parts of the outer walls was qualified as urgent. The repair should include masonry works on the most cracked, delaminated and displaced wall fragments as well as making expansion joints in the right places. Also, damaged brick pillars between the window openings were qualified for the repair masonry works. Moreover, it was recommended to re-profile the damage to the lintel beams with a simultaneous control of the condition of the invisible reinforced concrete column brackets on which they are based. Alternatively, the User was offered to replace the existing masonry curtain walls for new ones, made in the form of the light outer cladding of insulated sandwich panels.

In addition, it was recommended to immediately repair the leaky gutter and to ensure efficient drainage of rain water from downspouts out of the building premises.

\section{Summary}

The article presents a case of a damaged warehouse building built in the reinforced concrete precast technology, typical for the 60s and 70s of the last century. Damage and irregularities identified during the inspection were described and their causes were analyzed.

A precise identification of the type and extent of the damage led to the conclusion that the most important are the concrete cracks and losses along the edges of the load-bearing structure column heads at the level of the roof girders support, and not the cracks and displacements of the curtain wall fragments, which the user was most concerned with. 
There was no threat to the security of the structure confirmed, and its technical condition was rated as average. Having conducted the recommended repair works, the warehouse will be further used as intended.

The described example is a confirmation of a need to carry out regular evaluations of the technical condition of buildings, so that users can rationally plan renovation works for the further safe use of the structure.

\section{References}

[1] Ekspertyza stanu technicznego hali magazynowej w elektrowni. Akademia Górniczo-hutnicza w Krakowie, Wydział Geodezji Górniczej i Inżynierii Środowiska, Kraków 2010 [unpublished].

[2] Kluz T., Ciołek R., Szymański E.: Zagadnienia ogólne prefabrykacji. Budownictwo Betonowe, t. 7, Arkady, Warszawa 1972.

[3] PN-B-03002:2007: Konstrukcje murowe. Projektowanie i obliczanie.

[4] PN-B-03264:2002: Konstrukcje betonowe, ̇̇elbetowe i sprężone. Obliczenia statyczne i projektowanie.

[5] Rozporzadzenie Ministra Infrastruktury z dnia 12 kwietnia 2002 r. w sprawie warunków technicznych, jakim powinny odpowiadać budynki i ich usytuowanie. Dz.U. 2002, nr 75, poz. 690.

[6] Rozporządzenie Ministra Spraw Wewnętrznych i Administracji z dnia 16 sierpnia 1999 r. w sprawie warunków technicznych użytkowania budynków mieszkalnych. Dz.U. 1999, nr 74, poz. 836.

[7] Ustawa z dnia 7 lipca 1994 r. Prawo budowlane. Dz.U. 1944, nr 89, poz. 414.

[8] Wodyński A. 2007: Zużycie techniczne budynków na terenach górniczych. Uczelniane Wydawnictwa Naukowo-Dydaktyczne AGH, Kraków. 